\title{
Role of Interleukin-4 in Human Immunoglobulin E Formation in hu-PBL-SCID Mice
}

\author{
Hans L. Spiegelberg, ${ }^{*}$ Lucinda Beck, ${ }^{*}$ Hans P. Kocher, ${ }^{*}$ William C. Fanslow, ${ }^{5}$ and Alexander H. Lucas" \\ * Division of Pediatric Immunology and Allergy, Department of Pediatrics, University of California at San Diego, San Diego, California \\ 92093; ${ }^{\ddagger}$ Department of Biotechnology, Preclinical Research, Sandoz Pharma Ltd., CH-4002 Basel, Switzerland; ${ }^{\S}$ Immunex Research \\ and Development Corp., Seattle, Washington 98101; and "Children's Hospital Oakland Research Institute, Oakland, California 94609
}

\begin{abstract}
We studied the role of IL- 4 in human IgE formation in severe combined immunodeficient mice engrafted with peripheral blood mononuclear leukocytes (hu-PBL-SCID). PBL from four nonatopic donors produced only small $(<20 \mathrm{ng} / \mathrm{ml})$ or undetectable amounts of IgE in SCID mice whereas engrafted PBL from seven atopic donors secreted IgE with IgE serum levels reaching a mean $\pm \mathrm{SE}$ of $184 \pm 37 \mathrm{ng} / \mathrm{ml}(n=20)$. Serum IgE levels peaked 2-3 wk after PBL transfer and declined thereafter with a half-life of 1-2 wk. In contrast, IgG of all subclasses reached maximum serum levels 5-7 wk after PBL transfer and declined little thereafter. Injection of a neutralizing monoclonal antibody to the human IL-4 receptor (IL-4R) on day 0 inhibited completely the IgE formation and caused an approximate twofold reduction of IgG production of all subclasses. The anti-IL-4 R antibody had no effect on IgE secretion when administered 4 wk after PBL engraftment. Incubation of PBL with IL-4 before engraftment resulted in a 10-fold increase in IgE production and could be further enhanced by 100 fold if, in addition to preincubation with IL-4, IL-4 was injected daily for $\mathbf{5} \mathbf{d}$ after PBL transfer. This treatment with IL-4 also induced two- to threefold increase in IgG levels. IFN$\gamma$ had no effect on either IgE or IgG subclass production. In $\sim 50 \%$ of the mice, one or more IgG subclasses increased disproportionally 5 wk after PBL injection as a result of monoclonal IgG formation.

These data demonstrate that PBL from atopic donors secrete IgE in SCID mice in an IL-4-dependent manner, and that IgE production can be enhanced 10 - to 100 -fold with exogenous human IL-4 in these mice. This mouse model is amenable for the in vivo study of immunomodulators on human IgE formation.( J. Clin. Invest. 1994. 93:711-717.) Key words:IgE formation • IgG subclasses • human SCID mouse chimeras • interleukin- $4 \cdot$ interleukin- 4 receptor
\end{abstract}

A portion of this manuscript has been presented at the meetings of the Federation of American Societies of Experimental Biology, 5-9 April 1993, Anaheim, CA, and published in abstract form (1992. FASEB [Fed. Am. Soc. Exp. Biol.] 6:A1153).

Address correspondence to Dr. H. Spiegelberg, Division of Pediatric Immunology and Allergy, 0609D, UCSD School of Medicine, 9500 Gilman Dr., La Jolla, CA 92093-0609.

Received for publication 6 July 1993 and in revised form 7 September 1993.

J. Clin. Invest.

(c) The American Society for Clinical Investigation, Inc.

$0021-9738 / 94 / 02 / 0711 / 07 \$ 2.00$

Volume 93, February 1994, 711-717

\section{Introduction}

C.B-17 severe combined immunodeficient scid/scid (SCID) ${ }^{1}$ mice (1) engrafted with human PBL (hu-PBL-SCID) produce relatively large amounts of human $\operatorname{Ig}(2-6)$. The predominant isotype of the human Ig in hu-PBL-SCID mice is IgG with smaller quantities of $\operatorname{IgM}$ and $\operatorname{IgA}(3,4)$. The $\operatorname{IgG}$ consists of both polyclonal $\operatorname{IgG}(4)$ and specific antibodies $(5-10)$ with the latter especially being the case if the donor has been recently immunized (2) or if the PBL are incubated with antigen in vitro followed by immunization of the mice (6). PBL from autoimmune patients also secrete specific antibodies in huPBL-SCID mice (11-13). Therefore, the hu-PBL-SCID mouse model has great promise for studying the regulation of human Ig formation under in vivo conditions.

Recently, much has been learned regarding IgE regulation. IL-4 together with a second B cell activation signal $(14,15$, reviewed in 16) induces the IgM to IgE switch and subsequent IgE secretion in vitro. IFN- $\gamma$ as well as other lymphokines (14, 15 ) inhibit this process. However, little is known of the effect of these lymphokines on human IgE secretion in vivo. In clinical trials designed to evaluate a possible downregulatory effect of IFN- $\gamma$ on IgE antibody formation and allergic disease manifestations, no significant effect of IFN- $\gamma$ on the IgE serum level was observed $(17,18)$. Because new immunomodulators such as lymphokines can initially not be tested in man for ethical reasons, an animal model of human IgE formation would be desirable to obtain preclinical data on the effect of immunomodulators on human IgE formation in vivo. Saxon et al. (19) reported low or undetectable IgE serum levels in hu-PBL-SCID mice. The reason for this may be the low frequency of circulating IgE committed memory B cells in peripheral blood and/or the rare occurrence of the IgM to IgE switch in nonatopic humans. Ito et al. (20) showed that, in contrast to PBL from nonatopic patients, PBL from atopic donors secrete IgE in SCID mice, perhaps because B cells from atopics more readily switch to IgE than do B cells from nonatopics. In this study, we also investigated whether PBL from atopic humans would secrete IgE after transfer into SCID mice. In addition, we determined whether the IgE formation in hu-PBL-SCID mice is IL-4 dependent and whether culturing of PBL with human IL-4 and injection of IL-4 into the mice would increase the IgE production. We show that PBL from atopic donors secrete relatively large amounts of IgE in SCID mice, which is dependent on IL-4 production and its interaction with high affinity IL-4 receptors. This IgE production can be enhanced further with

1. Abbreviations used in this paper: hu-PBL-SCID, severe combined immunodeficient scid/scid mice (SCID) engrafted with human PBL; IL-4R, IL-4 receptor. 
exogenous IL- 4 treatment. Thus, SCID mice engrafted with PBL from atopic donors can serve as an animal model for studying human IgE formation in vivo.

\section{Methods}

Mice. C.B-17 scid/scid immunodeficient mice were bred and maintained at the Children's Hospital Oakland Research Institute (10) or the Animal Facilities of the University California at San Diego. Mice were housed in sterilized microbarrier units with sterilized bedding. They were provided autoclaved chow and water. To eliminate a small percent of "leaky" mice (21), the mice were bled and the mouse IgM and IgG serum level determined. Only mice having $<5$ ng mouse $\mathrm{IgM} / \mathrm{ml}$ or $<1 \mu \mathrm{g} \mathrm{IgG} / \mathrm{ml}$ were used for the experiments.

Human subjects and PBL isolation. PBL were isolated from heparinized peripheral venous blood by centrifugation through Ficoll-Hypaque and washed in RPMI 1640 medium containing $10 \%$ FCS. Blood from normal subjects was obtained from four adult volunteers who had no history of atopic disorders. The atopic donors consisted of four males and three females. Three had a history of atopic dermatitis and/ or asthma and allergic rhinitis but were healthy at the time of blood donation. Four patients had active atopic dermatitis and had not taken oral corticosteroids for $\geq 24 \mathrm{~h}$ before blood donation. Informed consent was obtained from all donors. PBL were either injected on the same day of isolation or in some experiments after overnight shipment from La Jolla to Oakland. Preliminary data showed that the IgG and IgE levels were not significantly different between SCID mice receiving fresh PBL or PBL maintained for $24 \mathrm{~h}$ at $4^{\circ} \mathrm{C}$. The cells were washed and resuspended in RPMI 1640 medium without FCS immediately before injection. SCID mice received $40 \times 10^{6} \mathrm{PBL}$ intraperitoneally, except for one experiment with PBL from an atopic donor, where 27 $\times 10^{6}$ cells/mouse where injected because of low PBL yield.

$I L-4$ and IFN- $\gamma$. IL-4 was isolated from culture supernatants of Chinese hamster ovary cells transfected with human IL-4 DNA. The cell supernatant was concentrated 50 -fold by ultrafiltration and subjected to ion-exchange chromatography on S-Sepharose FF (Pharmacia Fine Chemicals, Piscataway, NJ) in 20-mM sodium citrate buffer at $\mathrm{pH}$ 5.5. IL-4 was eluted from the column with starting buffer containing $800 \mathrm{mM}$ sodium chloride. Active fractions were pooled and subjected to reversed-phase chromatography on a C4 column (VYDAC, Hesperia, CA) equilibrated with $0.1 \%$ trifluoroacetic acid. IL-4 was eluted by gradient elution with acetonitrile containing $0.1 \%$ trifluoroacetic acid. The isolated recombinant IL-4 showed one band in SDSPAGE, gave a single peak in analytical reversed-phase HPLC, and it had a bioactivity of $10^{7} \mathrm{U} / \mathrm{mg}$ when tested for half-maximum proliferation of human $T$ cells suboptimally activated with phytohemagglutinin. $5 \mathrm{~h}$ after injection of $10 \mu \mathrm{g}$ IL-4 i.p. into normal mice, the IL-4 serum level was $\sim 600 \mathrm{ng} / \mathrm{ml}$ and declined thereafter with a half-life of $20 \mathrm{~min} .24 \mathrm{~h}$ after intraperitoneal injection of the IL-4, the serum contained $<30 \mathrm{pg} \mathrm{IL}-4 / \mathrm{ml}$. The IL-4 levels were measured with a modified radioimmunoassay (22) using two monoclonal antibodies to IL-4 prepared in our laboratory. A monoclonal murine IgG1 anti-IL-4 receptor antibody (M57) was isolated from cultured hybridoma cells supernatant by absorption to a protein A-Sepharose 4B column (23). Recombinant IFN- $\gamma$ (Genentech, Inc., South San Francisco, CA) for human use was a gift from Dr. John Bastian (Children's Hospital, San Diego, CA).

IgE and IgG subclass determinations. Mice were bled from the retroorbital venous plexous and the blood was allowed to clot. The serum was then collected and stored at $-20^{\circ} \mathrm{C}$. The IgE and IgG serum levels were determined by radioimmunoassays previously described (22). Briefly, a mixture of two monoclonal antibodies to $\operatorname{lgE}$ ( 7.15 and 4.12), kindly provided by Dr. Andrew Saxon (UCLA, Los Angeles, CA) or the monoclonal antibodies to IgG subclasses IgG1 (HP-6012), IgG2 (HP-6002), IgG3 (HP-6050), and IgG4 (HP-6023) were captured onto 96-well polyvinyl plates with either goat anti-mouse IgGI or IgG3 (Southern Biotechnology Co., Birmingham, AL). Standards and serum dilutions were incubated overnight, and the amount of IgE or IgG subclasses bound to the plates was detected with either purified goat anti-IgE or anti-IgG prepared in our laboratory. The sensitivity of the RIA was $0.4 \mathrm{ng} \mathrm{IgE} / \mathrm{ml}$ and $0.2-0.8 \mathrm{ng} \mathrm{IgG}$ for the different $\mathrm{IgG}$ subclasses. Electrophoresis of undiluted serum was performed on cellulose acetate membranes with a Beckman Instruments (Carlsbad, CA) electrophoresis apparatus as previously described for human myeloma sera (24).

Statistical analyses. The data were analyzed statistically by the Student's $t$ test.

\section{Results}

Human IgE production in SCID mice engrafted with PBL from nonatopic and atopic donors. 22 SCID mice were injected with PBL from four nonatopic donors, and 61 SCID mice were injected with PBL from seven atopic donors. Of these mice, seven injected with PBL from either nonatopic or atopic donors had $<100 \mu \mathrm{g} \mathrm{IgG} / \mathrm{ml}$, whereas the others had $>2.5 \mathrm{mg} \mathrm{IgG/ml}$. The mice with low IgG levels were considered as poorly engrafted and were not studied further. The IgE levels in 18 mice injected with PBL from nonatopic donors were $<20 \mathrm{ng} / \mathrm{ml}$. In contrast, all mice injected with PBL from the atopic donors had easily measurable IgE with a mean \pm SE maximum serum level of $184 \pm 37 \mathrm{ng} / \mathrm{ml}$ (range $=29-997 \mathrm{ng} / \mathrm{ml}$ ) in 20 mice injected with PBL from 7 atopic donors. Considerable variation in IgE serum levels was observed between mice injected with PBL from different donors and also between different mice injected with PBL from the same donor. As shown in Fig. 1., mice engrafted with PBL from an atopic dermatitis patient produced low levels of IgE as early as 1 wk after PBL injection, and peak serum levels were reached 2-3 wk after PBL engrafting. After 2-3 wk, the IgE levels declined with a half-life of 1-2 wk. No correlation was observed between the peak IgE serum level in the mice and either the donor's atopic disease activity, IgE serum level or the IgE spontaneously secreted by the donor's PBL cultured in vitro for $10 \mathrm{~d}$ (data not shown).

Whereas the IgE serum levels typically declined in most mice after reaching a maximum level 2-3 wk after the PBL injection, in one exceptional mouse, the IgE level rose from about $250 \mathrm{ng} / \mathrm{ml}$ to $2,000-3,000 \mathrm{ng} / \mathrm{ml}$ between weeks 5 and 7 (Fig. 2) and remained at this level $\leq 14$ wk after the PBL engraftment when the mouse was killed. As described below for IgG subclasses, this increase was most likely the result of a monoclonal expansion of IgE producing B cells in this mouse.

IgG subclass levels in hu-PBL-SCID mice engrafted with $P B L$ from nonatopic and atopic donors. All hu-PBL-SCID mice produced the four subclasses of IgG. The sum of the four IgG

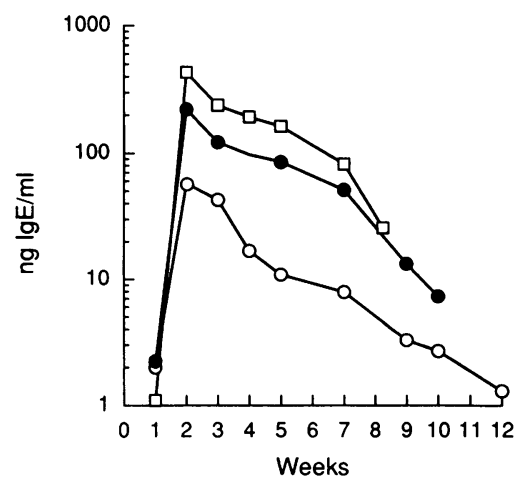

Figure 1. IgE serum levels in three SCID mice injected with $40 \times 10^{6}$ PBL from atopic dermatitis patient 8 . 


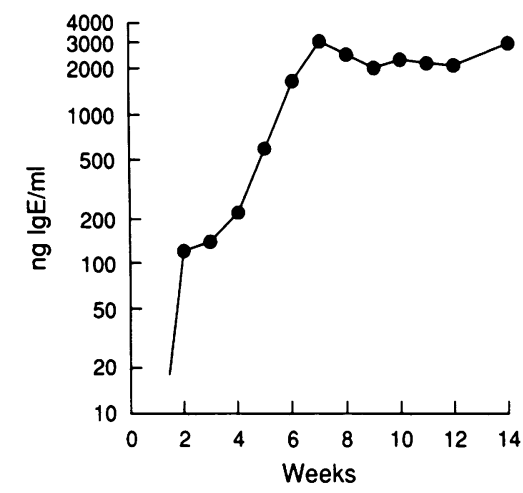

Figure 2. IgE serum level in a SCID mouse injected with $40 \times 10^{6}$ PBL from atopic dermatitis patient 10 . subclasses agreed with the total IgG (not $>22 \%$ difference) indicating the accuracy of the IgG subclass determinations. As shown in Fig. 3 for a mouse injected with PBL from an atopic dermatitis patient, the IgG subclass levels reached a maximum 3-5 wk after PBL engraftment, by which time the IgE level already had declined. In almost all mice, the IgG3 level was initially higher than the IgG4 level but declined or did not increase as much as the IgG4 level 3-7 wk after the graft. This result is most likely accounted for by the shorter half-life of human IgG3 than that of the other subclasses in mice (25). At 3 wk after PBL engraftment, the IgG subclass distribution was similar to that in normal serum in mice injected with PBL from nonatopic or atopic subjects (Table I). On average, the mice injected with PBL from atopic donors had higher total IgG and higher IgG subclass levels than mice injected with PBL from nonatopic donors, but this difference was not significant ( $P$ $>0.05$ ).

The proportion of the four IgG subclasses in the hu-PBLSCID mice remained relatively constant for 5-7 wk. Thereafter, one or two IgG subclasses increased disproportionally in about half of the mice. This is shown in Fig. 4 for a hu-PBLSCID mouse, which after $5 \mathrm{wk}$ showed a marked increase in the IgG1 level that by week 7 exceeded the levels of the other subclasses by nearly 100-fold. This increase was the result of a clonal expansion of IgG producing B cells as shown by monoclonal bands in serum electrophoresis (Fig. 5). Details of the monoclonal Ig production in hu-PBL-SCID mice occurring 5 wk after the PBL injection will presented elsewhere (Spiegelberg, H. L., L. Beck, and A. H. Lucas, manuscript in preparation).

Effect of a monoclonal anti-IL-4 receptor antibody on IgE and IgG production in hu-PBL SCID mice. PBL from an atopic donor whose cells consistently secreted IgE in SCID mice were injected into the SCID mice together with $1 \mathrm{mg}$ of a murine

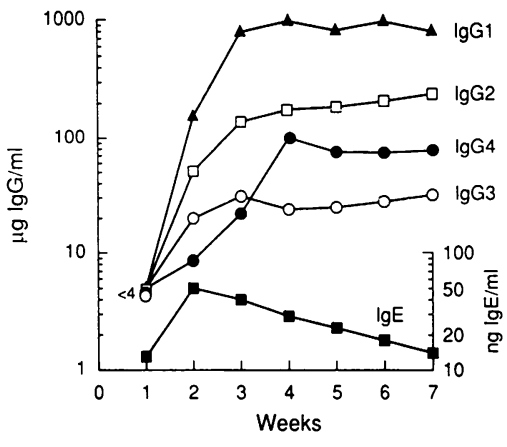

Figure 3. IgE and IgG subclass serum levels in a SCID mouse injected with $40 \times 10^{6}$ PBL from atopic dermatitis patient 7 .
IgG1 monoclonal anti-human IL-4 receptor (IL-4R) antibody (23). Control mice received $1 \mathrm{mg}$ of murine $\mathrm{IgG} 1$ of no known antibody specificity. As shown in Table II, all control mice produced IgE after PBL engraftment, whereas the IgE serum level in the mice receiving anti-IL-4R antibodies was not measurable during the first 4 wk after the PBL injection. The mice injected with the anti-IL-4R antibody had lower IgG subclass levels than the control mice. However, no particular subclass, especially not $\mathrm{IgG} 4$, was preferentially suppressed.

Two control mice that had high IgE serum levels were injected 4 wk after the PBL engraftment with $1 \mathrm{mg}$ anti-IL-4R antibody to determine whether this antibody inhibited ongoing IgE formation. Injection of this antibody had no effect on the slowly declining IgE level in these mice.

Effect of IL-4 on the IgE and IgG subclass formation in $h u-P B L-S C I D$ mice. PBL from the two atopic donors, who were free of disease at the time of blood donation, were preincubated with $500 \mathrm{U} \mathrm{IL}-4 / \mathrm{ml}$ for $24 \mathrm{~h}$ before injection into SCID mice. In addition, four mice were injected with $10 \mu \mathrm{g}$ IL-4 i.p. daily for $5 \mathrm{~d}$ after the PBL graft. As shown in Fig. 6, the four mice injected with IL-4 attained a mean IgE serum level of $11,900 \mathrm{ng} \mathrm{IgE} / \mathrm{ml}$, which is 100 -fold higher than in the control mice. The IgE level in the control mice reached a maximum 3 wk after PBL engraftment, whereas the maximum IgE level in IL-4-treated mice occurred $6 \mathrm{wk}$ after grafting. Also, the IgE level in the IL-4-treated mice declined only slowly thereafter with a half-life of 5-6 wk as compared to 1-2 wk for the controls. Preincubation of the PBL from the same donors with IL-4 but without subsequent injection of IL-4 into mice, also enhanced IgE production (mean \pm SE peak serum level of $1,120 \pm 230 \mathrm{ng} / \mathrm{ml} \mathrm{IgE}$ ) but not to the extent observed with in vivo IL-4 treatment (Table III).

Three hu-PBL-SCID mice were injected on days 28-32 with $10 \mu \mathrm{g}$ IL-4 i.p. IgE levels did not increase in any of these

Table I. Human IgE and IgG Subclass Formation in hu-PBL-SCID Mice Engrafted with PBL from Nonatopic and Atopic Donors*

\begin{tabular}{|c|c|c|c|c|c|c|}
\hline \multirow[b]{2}{*}{ Donor } & \multirow[b]{2}{*}{ IgE } & \multirow[b]{2}{*}{$\operatorname{IgG}$} & \multicolumn{4}{|c|}{ Percent IgG subclass (mean \pm SD) } \\
\hline & & & IgG1 & $\operatorname{lgG} 2$ & $\operatorname{lgG} 3$ & IgG4 \\
\hline & $n g / m l$ & $\mu g / m l$ & & & & \\
\hline Nonatopic & $<20$ & $706 \pm 330$ & $69.4 \pm 12.2$ & $20.8 \pm 10.1$ & $2.5 \pm 1.2$ & $7.3 \pm 3.3$ \\
\hline Atopic dermatitis & $129 \pm 38$ & $1,136 \pm 479^{\ddagger}$ & $69.1 \pm 8.8$ & $16.0 \pm 4.6$ & $5.7 \pm 4.5$ & $9.2 \pm 6.7$ \\
\hline
\end{tabular}

* IgE and IgG values determined in sera obtained 3 wk after engraftment with PBL from three nonatopic humans and three patients with atopic dermatitis; mean $\pm \mathrm{SD}$ of nine and eight mice, respectively. ${ }^{\ddagger} P>0.05$, the other differences were also statistically not significant. 


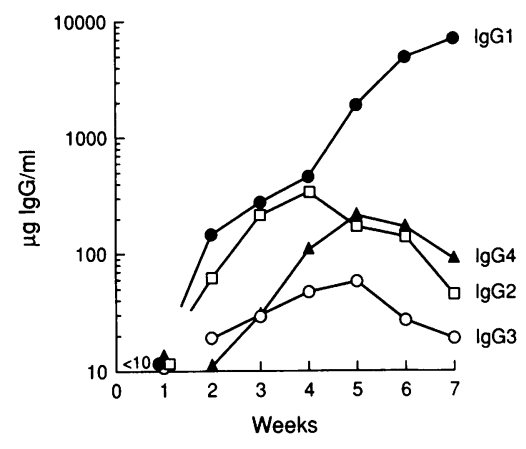

Figure 4. IgG subclass serum levels in a SCID mouse injected with 40 $\times 10^{6}$ PBL from nonatopic donor 4 .

mice, indicating that IL-4 was no longer able to induce IgE formation $4 \mathrm{wk}$ after the PBL graft.

IL-4 also affected the IgG production. Culturing of the PBL with IL-4 followed with or without subsequent injection of IL-4 into the mice resulted in a two- to threefold increase of the total IgG serum level as compared to the control mice (Table III). The IgG2 level rose proportionately more than that of the other subclasses $(P<0.05)$. The increase of the percentage of IgG4 and total level of IgG4 was greater in mice injected with IL-4 as compared to the control mice, however, neither difference was significant $(P>0.1)$.

Effect of IFN- $\gamma$ on IgE production. Three mice engrafted with PBL from an atopic donor were injected with $10 \mu \mathrm{g}$ IFN$\gamma /$ mouse daily on days $0-5$. In addition, PBL that were first cultured for $24 \mathrm{~h}$ with $10 \mathrm{ng}$ IFN- $\gamma / \mathrm{ml}$ were injected into two mice, and the mice were injected daily with $10 \mu \mathrm{g} \mathrm{IFN}-\gamma$ for $5 \mathrm{~d}$. This treatment neither affected the IgE nor IgG subclass formation in these mice. The mean peak IgE level was $109 \mathrm{ng} \mathrm{IgE} / \mathrm{ml}$ in the five IFN- $\gamma$ treated mice as compared to $113 \mathrm{ng} \mathrm{IgE} / \mathrm{ml}$ for six control mice injected with PBL from the same donor. The mean percentages of the four IgG subclasses, $3 \mathrm{wk}$ after the PBL engraftment, were $74 \%$ IgG 1, 21\% IgG2, 2\% IgG3, and 3\% IgG4 in the IFN- $\gamma$-treated mice, and these values were similar to the percentages in control mice (Table III).

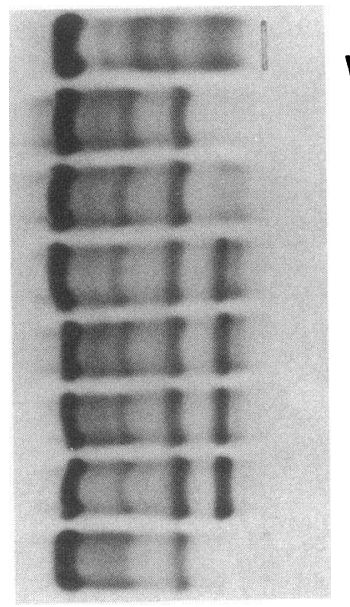

\section{Week Normal human serum 3} 5

\section{Normal mouse serum}

Figure 5. Cellulose acetate serum electrophoresis of sera obtained 3-20 wk after the PBL graft from a SCID mouse injected with PBL from atopic donor 5 . The serum shows two monoclonal bands $3 \mathrm{wk}$ after the PBL graft. Thereafter, one of the bands increased, whereas the other decreased and disappeared $20 \mathrm{wk}$ after the PBL graft. The IgG1 serum level was $13,400 \mu \mathrm{g} / \mathrm{ml} 20$ wk after the PBL graft, and the IgG2 level was $1,990 \mu \mathrm{g} / \mathrm{ml} 7$ wk after the PBL graft.

Table II. The Effect of a Monoclonal Antibody to the IL-4 Receptor on the IgE and IgG Subclass Formation in hu-PBL SCID Mice 4 wk after Injection of PBL from an Atopic Donor

\begin{tabular}{lllllll}
\hline Mouse No. & $\operatorname{IgG1}$ & $\operatorname{IgG} 2$ & $\mathrm{IgG} 3$ & $\mathrm{IgG} 4$ & $\Sigma \mathrm{IgG}$ & $\operatorname{IgE}$ \\
\hline & $\mu \mathrm{g} / \mathrm{ml}$ & & & $\mathrm{ng} / \mathrm{ml}$
\end{tabular}

Controls

$\begin{array}{rrrrrrr}9-1 & 1,442 & 995 & 44 & 25 & 2,658 & 474 \\ 9-2 & 1,409 & 658 & 34 & 129 & 2,207 & 398 \\ 9-3 & 1,045 & 628 & 25 & 25 & 2,038 & 214\end{array}$

Anti-IL-4 receptor M57, $1 \mathrm{mg}$ i.p. on day 0

\begin{tabular}{lrrrrrr}
$9-5$ & 849 & 250 & 11 & 48 & 1,158 & $<2$ \\
$9-6$ & 850 & 223 & 21 & 19 & 1,113 & $<2$ \\
$10-3$ & 1,00 & 346 & 8 & 32 & 1,380 & $<2$ \\
\hline
\end{tabular}

\section{Discussion}

This study shows that PBL from atopic patients, in contrast to PBL from nonatopic donors, secrete relatively large amounts of IgE after transfer into SCID mice, confirming the data of Ito et al. (20). This IgE formation is dependent on IL-4 interaction with the high affinity IL-4R, as it was completely suppressed by injection of a monoclonal antibody to this receptor. Furthermore, human IgE production could be enhanced $\sim 100$-fold in the SCID mice by first culturing the PBL with IL-4, followed by injecting IL-4 into the mice for the first $5 \mathrm{~d}$ after PBL transfer. Even culturing the cells with IL- 4 alone for $24 \mathrm{~h}$ before transfer resulted in a 10 -fold increase in IgE production. After reaching peak levels 2-5 wk after the PBL graft, the IgE serum levels declined slowly over a several week period in a predictable exponential manner. The elevated human IgE production in hu-atopic-PBL-SCID mice, and the predictable slow decline of the IgE serum level, demonstrate that this model should be amenable for studying the effects of immunoregulators on the initiation of IgE secretion and ongoing human IgE production in vivo.

The lack of IgE formation in hu-PBL-SCID mice grafted with cells from nonatopics confirms previous observations ( 19 , 20 ) and suggests that cells from nonatopic subjects contain no or few memory B cells that become activated to secrete IgE in SCID mice, nor do they have B cells that undergo an IgM to IgE switch in the mice. In contrast, PBL from atopic donors spontaneously secreted IgE after transfer into SCID mice, which has

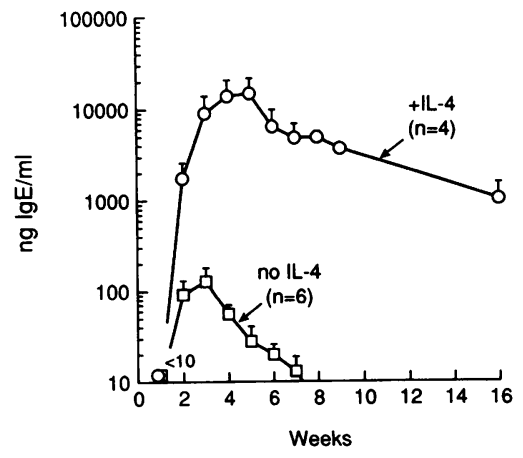

Figure 6. The effect of IL-4 on the IgE serum levels in SCID mice. The PBL were incubated for $24 \mathrm{~h}$ with 500 U IL- $4 / \mathrm{ml}$, and the mice were injected with $10 \mu \mathrm{g} \mathrm{IL}-4$ i.p. for $5 \mathrm{~d}$ after the PBL graft. Mean \pm SE of four mice injected with IL-4 (O) and six control mice (口) receiving $\mathrm{PBL}$ from the same donor. 


\begin{tabular}{|c|c|c|c|c|c|c|}
\hline & \multirow[b]{2}{*}{ IgE } & \multirow[b]{2}{*}{ IgG } & \multicolumn{4}{|c|}{ Percent IgG subclass (mean \pm SE) } \\
\hline & & & IgG1 & IgG2 & IgG3 & IgG4 \\
\hline & $n g / m l$ & $\mu g / m l$ & & & & \\
\hline No IL-4 $(n=5)$ & $183 \pm 78$ & $697 \pm 179$ & $67 \pm 10$ & $22 \pm 7$ & $4 \pm 2$ & $7 \pm 3$ \\
\hline \multicolumn{7}{|l|}{$\mathrm{IL}-4(n=4)^{\ddagger}$} \\
\hline in vitro and in vivo & $11,915 \pm 998$ & $1,630 \pm 550$ & $47 \pm 5$ & $41 \pm 3^{\S}$ & $2 \pm 0.5$ & $10 \pm 3$ \\
\hline \multicolumn{7}{|l|}{ IL-4 $(n=5)^{\ddagger}$} \\
\hline in vitro only & $1,120 \pm 230$ & $1,144 \pm 273$ & $52 \pm 9$ & $36 \pm 7^{\S}$ & $3 \pm 0.4$ & $9 \pm 4$ \\
\hline
\end{tabular}

* IgE and IgG concentrations $3 \mathrm{wk}$ after PBL injection from atopic donors 5 and $6 .{ }^{\ddagger} \mathrm{PBL}$ were preincubated for $24 \mathrm{~h}$ with $500 \mathrm{U}$ IL-4/ml; the mice were injected with $10 \mu \mathrm{g} \mathrm{IL}-4 / \mathrm{d}$ i.p. for $5 \mathrm{~d}$. ${ }^{\S} P=0.05$, the other differences between the three groups were not significant $(P>0.05)$.

also been reported by Ito et al. (20). This IgE formation was IL-4 dependent, as shown by its inhibition with antibodies to the IL-4 receptor. Since IL-4 is required for the IgE-specific switching (14-16), the IgE was most likely derived from previously uncommitted B cells that had undergone a T cell- and IL-4-dependent isotype switch in the mice. Further support for this assumption is provided by Ito et al. (20), who demonstrated that PBL from atopic patients that are depleted of $\mathrm{DC4}^{+} \mathrm{T}$ helper cells do not secrete IgE in SCID mice. The IgE also could have been derived from circulating IgE committed memory B cells, although this appears less likely in as much as the IgE production in the SCID mice did not correlate with the spontaneous IgE production in vitro of the PBLs. Also, the anti-IL-4R antibody blocked all IgE formation indicating that the IgE production was IL-4 dependent. The anti-IL-4R antibody had no effect on the IgE production when injected $4 \mathrm{wk}$ after the PBL graft indicating that, once established, IgE production is no longer IL-4 dependent and is produced by IgE committed B or plasma cells. The peripheral blood of atopic patients apparently contains few B cells that spontaneously secrete IgE in a $\mathrm{T}$ cell- and IL-4-independent manner. Injection of B cells into SCID mice does not result in detectable IgE formation (20).

The kinetics of IgE formation in the SCID mice differed for untreated and IL-4 exposed PBL. IgE produced by untreated PBL reached peak serum levels 2-3 wk after the PBL graft and declined thereafter with a half-life of 1-2 wk. In contrast, the IgE level reached peak values 4-5 wk after engraftment of IL4-treated PBL, and the IgE serum level declined slowly with a half-life of $\sim 6 \mathrm{wk}$. These findings suggest that PBL from atopic patients contain B cells that, upon transfer into SCID mice, are capable of maturing rapidly into IgE secreting cells but are relatively short lived in the absence of exogenous IL-4. The reason for this is unknown. Perhaps these cells secrete IgE for only a brief period because of a lack of continuous stimulation in the SCID mice. Spontaneous human antibody production ceases soon after the PBL transfer into SCID mice if the cells are not first activated with antigen or if the mice are not subsequently immunized $(6,7,10)$. Perhaps both $\operatorname{IgE}$ and $\operatorname{IgG}$ secretion that occurs after the engraftment of PBL into SCID mice is derived from relatively short-lived B cells. Continuous Ig secretion appears to require antigenic stimulation and $\mathrm{T}$ cell activation.

IL-4 not only induced IgE formation, but also enhanced IgG production by two- to threefold in the hu-PBL-SCID mice. In vitro, IL-4 induces IgE and IgG4 secretions (22, 26-28).
Although the IgG4 levels were increased in hu-PBL-SCID mice injected with IL-4, the increase was statistically not significant. IL-4 treatment in vitro induces PBLs to secrete similar amounts of $\operatorname{IgE}$ and $\operatorname{IgG} 4(22,26)$. In the hu-PBL-SCID mice, IL-4 induced a mean IgE serum level of approximately $12 \mu \mathrm{g}$ $\mathrm{IgE} / \mathrm{ml}$. IL-4 also may have induced $\mathrm{B}$ cells to switch and secrete a similar quantity of IgG4, but the difference between IL-4 exposed and control PBL would have been too small to be detected since the PBL secreted spontaneously over $100 \mu \mathrm{g}$ $\mathrm{IgG} 4 / \mathrm{ml}$. Although IL-4 induced an increase of all IgG subclass serum levels, $\mathrm{IgG} 2$ was proportionately increased more than the other subclasses. It is unlikely that IL-4 induced the switch of uncommitted B cells to all four IgG subclasses since this is not observed in vitro $(22,26,28)$. More likely, IL-4, in addition to inducing the $\mathrm{IgE}$ and $\mathrm{IgG} 4$ switch, acts as a growth factor for all B cells, which leads to an increase in all Ig isotypes. Peripheral blood contains relatively high numbers of sIgG2-positive B cells (29), and if IL-4 acts as a growth factor for all B cells, this could explain the proportional increase of IgG2. Also, IL-4 could indirectly enhance IgG production. Carlsson et al. (7) showed that removal of natural killer cells from the PBL graft results in enhanced IgG secretion. Thus, it is possible that IL-4 suppressed this natural killer cell action or had additional effects on cells that inhibit $\mathrm{IgG}$ formation in SCID mice.

The IgG subclass distribution in hu-PBL-SCID mice 3-5 wk after the PBL graft was similar to that of normal human serum. Thereafter, one or two IgG subclasses increased rapidly and disproportionately in $\sim 50 \%$ of the mice. A similar rapid increase in the IgE level occurred in one mouse, although it reached only $3 \mu \mathrm{g} / \mathrm{ml}$ as compared to $2-8 \mathrm{mg} \mathrm{IgG/ml}$. This restricted increase appears to be the result of a monoclonal expansion of $B$ cells as shown by monoclonal spikes in cellulose acetate electrophoresis, similar to those seen in patients with monoclonal gammopathy (24). Such monoclonal bands have also been observed in the hu-PBL-SCID mice by others, although they often are referred to as oligoclonal peaks $(4,7,30$, 31 ). Saxon et al. (19) showed that the $\operatorname{IgG} \kappa / \lambda$ ratio is skewed in many SCID mice $\geq 5 \mathrm{wk}$ after the PBL injection. These investigators interpreted the abnormal $\kappa / \lambda$ ratios as the result of a limited number of $B$ cell clones that successfully engrafted in the SCID mice. Our findings demonstrate that the initial IgG subclass distribution is similar to that in normal human serum and that a skewing of the IgG subclass ratios occurs only $5 \mathrm{wk}$ after the PBL engrafting. This result suggests that PBL in SCID mice initially mainly produce polyclonal Ig, but at later times, a 
limited number of B cells expand monoclonally causing the skewed IgG subclass and $\kappa / \lambda$ ratios. Monoclonal expansion may result from expansion of EBV-transformed $\mathrm{B}$ cells, although monoclonal Ig has also been observed in hu-PBL-SCID mice grafted with PBL from EBV-negative donors (30, 31 ). No overt lymphomas were detected upon autopsy in our mice after terminating the experiments indicating that the monoclonal B cell expansion was limited in mass. Alternatively, monoclonal expansion could result from selective activations of B cells reactive with mouse tissue antigens (7). Perhaps the growth of these B cells is under $\mathrm{T}$ cell control. It was shown that the $\mathrm{T}$ cells decrease to a small number several weeks after the PBL engraftment (32). This may allow the B cells to expand in a monoclonal manner. As shown by Ito et al. (20), two of three mice injected with CD8-depleted PBL from an atopic donor showed a sudden increase in the IgE level 5-6 wk after PBL transfer, whereas this was not the case in the three control mice receiving unfractionated PBL. This suggests that $C D 8^{+} T$ cells may inhibit the monoclonal Ig formation. Interestingly, a human SCID patient who was given a bone marrow graft also showed monoclonal Ig including IgE, which disappeared after a second graft that resulted in $T$ cell engraftment (33).

The objective of this study was to define the conditions for human IgE secretion in hu-PBL-SCID mice. By using PBL from atopics and exposing the cells to IL-4, we have shown that PBL secrete large quantities of IgE for a long period of time in SCID mice. Most likely this IgE is polyclonal in nature. However, in a small percentage of mice it is possible that monoclonal IgE production can occur 5-6 wk after PBL injection. Therefore, the hu-PBL-SCID model involving PBL from atopic patients is most useful for studying the effect of immunomodulators on IgE formation during the first 5 wk of engraftment. This is illustrated by the effects of an anti-IL- 4 receptor antibody and of IFN- $\gamma$ on the IgE secretion in hu-PBL mice. The anti-IL-4R antibody completely inhibited all IgE secretion during the initial weeks after PBL injection. Although IFN- $\gamma$ inhibits IL-4-induced IgE secretion in vitro $(14,15)$, it did not inhibit the IgE formation in the hu-PBL-SCID mice. This is analogous to the lack of an effect of IFN- $\gamma$ on the IgE serum levels in atopic patients $(17,18)$. This concordant ineffectiveness of IFN- $\gamma$ on IgE secretion in vivo demonstrates that immunoregulators of human IgE formation have to be tested in vivo, such as in hu-atopic-PBL-SCID mice, to evaluate their possible beneficial therapeutic effect in man.

\section{Acknowledgments}

We thank Drs. Tom Kipps and Michel Duchosal for allowing us to use their SCID mouse facility and for advice, Drs. R. Zeiger, R. O'Connor, and W. Plescow for blood from atopic dermatitis patients, Dr. Rita Roth for performing some of the IgE and IgG subclass analyses, Ms. Marina Kitamura and Patricia Charos for skillful care of the SCID mice, and Ms. Kelley Grant for typing the manuscript.

This work was supported by National Institutes of Health Asthma, Allergic and Immunologic Diseases Cooperative Research Center grants AI-31595 and AI-25008 to Dr. A. Lucas.

\section{References}

1. Bosma, G. C., R. P. Custer, and M. J. Bosma. 1983. A severe combined immunodeficiency mutation in the mouse. Nature (Lond.). 301:527-530.

2. Mosier, D. E., R. J. Gulizia, S. M. Baird, and D. B. Wilson. 1988. Transfer of a functional human immune system to mice with severe combined immunodeficiency. Nature (Lond.). 335:256-259.
3. Mosier, D. E. 1990. Immunodeficient mice xenografted with human lymphoid cells: new models for in vivo studies of human immunobiology and infectious diseases. J. Clin. Immunol. 10:185-191.

4. Abedi, M. R., B. Christensson, K. B. Islam, L. Hammarström, and C. I. E. Smith. 1992. Immunoglobulin production in severe combined immunodeficient (SCID) mice reconstituted with human peripheral blood mononuclear cells. Eur. J. Immunol. 22:823-828.

5. Mazingue, C., F. Cottrez, C. Auriault, J. Y. Cesbon, and A. Capron. 1991. Obtention of a primary humoral response against schistosome protective antigens in severe combined immunodeficiency mice after the transfer of human peripheral blood mononuclear cells. Eur. J. Immunol. 21:1763-1766.

6. Duchosal, M. A., S. A. Eming, P. Fischer, D. Leturcg, C. F. Barbas, P. J. McLoughey, R. H. Couthien, G. B. Thornton, F. J. Dixon, and D. R. Burton. 1992. Immunization of hu-PBL-SCID mice and the rescue of human monoclonal IgG fragments through combinatorial libraries. Nature (Lond.). 355:258-262.

7. Carlsson, R., S. Martensson, M. Kalliomaki, M. Ohlin, and C. A. Borrebaek. 1992. Human peripheral blood lymphocytes transplanted into SCID mice constitute an in vivo culture system exhibiting several parameters found in normal humoral immune response and are a source of immunocytes for the production of human monoclonal antibodies. J. Immunol. 148:1065-1071.

8. Williams, S. S., T. Umeoto, H. Kida, E. A. Repasky, and R. B. Bankert. 1992. Engraftment of human peripheral blood leukocytes into severe combined immunodeficient mice results in the long term and dynamic production of human xenoreactive antibodies. J. Immunol. 149:2830-2836.

9. Aaberge, I. S., T. E. Michaelsen, A. K. Rolstad, E.-C. Groeng, P. Solberg, and M. Lovik. 1992. SCID-Hu mice immunized with pneumococcal vaccine produce specific human antibodies and show increased resistance to infection. Infect. Immun. 60:4146-4153.

10. Lucas, A. H., T. E. Siff, K. H. Trujillo, and M. Y. Kitamura. 1992. Vaccine induced human antibody response to the Haemophilus influenzae b polysaccharide in severe combined immunodeficient mice engrafted with human leucocytes. Pediatr. Res. 32:132-135.

11. Duchosal, M. A., P. J. McConahey, C. A. Robinson, and F. J. Dixon. 1990. Transfer of human systemic lupus erythematosus in SCID mice. J. Exp. Med. 172:985-988.

12. Macht, L., N. Fukuma, K. Leader, D. Sarsero, C. A. Pegg, D. I. Phillips, P. Yates, S. M. McLachlan, C. Elson, and B. Rees Smith. 1991. Severe combined immunodeficient (SCID) mice: a model for investigating human thyroid autoantibody synthesis. Clin. Exp. Immunol. 84:34-42.

13. Davies, T. F., H. Kimura, P. Fong, D. Kendler, L. D. Shultz, S. Thung, and A. Martin. 1991. The SCID-hu mouse and thyroid autoimmunity: characterization of human thyroid autoantibody secretion. Clin. Immunol. Immunopathol. 60:319-330.

14. Coffman, R. L., and J. Carty. 1986. A T cell activity that enhances polyclonal IgE production and its inhibition by IFN- $\gamma$. J. Immunol. 136:949-954.

15. Pène, J., F. Rousset, F. Brière, I. Chrétien, J.-Y. Bonnefoy, H. Spits, T. Yokota, N. Arai, K.-I. Arai, J. Banchereau, and J. E. De Vries. 1988. IgE production by normal human lymphocytes is induced by interleukin 4 and suppressed by interferons $\gamma$ and $\beta$ and prostaglandin $\mathrm{E}_{2}$. Proc. Natl. Acad. Sci. USA. 85:6880-6884.

16. Vercelli, D., and R. S. Geha. 1991. Regulation of IgE synthesis in humans: A tale of two signals. J. Allergy Clin. Immunol. 88:285-295.

17. Li, J. T. C., J. W. Yunninger, C. E. Reed, H. S. Jaffe, D. R. Nelson, and G. J. Gleich. 1990. Lack of suppression of IgE production by recombinant interferon gamma: a controlled trial in patients with atopic rhinitis. J. Allergy Clin. Immunol. 85:934-940.

18. Baguniewicz, M., H. S. Jaffe, A. Izu, M. J. Sullivan, D. York, and R. S. Geha. 1990. Recombinant gamma interferon in treatment of patients with atopic dermatitis and elevated IgE levels. Am. J. Med. 88:365-665.

19. Saxon, A., E. Macy, K. Denis, M. Tary-Lehmann, O. Witte, and J. Braun. 1991. Limited B cell repertoire in severe combined immunodeficient mice engrafted with peripheral blood mononuclear cells derived from immunodeficient or normal humans. J. Clin. Invest. 87:658-665.

20. Ito, M., G. Matsuzaki, S. Uno, Y. Katakai, M. Suko, S. Endo, and H. Okudaira. 1992. Regulation of human IgE production by peripheral blood mononuclear cells from atopic patients in mice with severe combined immunodeficiency. Int. Arch. Allergy Immunol. 99:373-376.

21. Bosma, G. C., M. Fried, R. P. Custer, A. Carroll, D. M. Gibson, and M. J. Bosma. 1988. Evidence of functional lymphocytes in some (leaky) SCID mice. $J$. Exp. Med. 167:1016-1033.

22. Nüsslein, H., and H. L. Spiegelberg. 1990. Interleukin-4 induces both IgG4 and IgE secretion by peripheral blood B cells. J. Clin. Lab. Anal. 4:414-419.

23. Fanslow, W. C., M. K. Spriggs, C. T. Rauch, K. N. Clifford, B. M. MacDuff, S. F. Ziegler, K. A. Schooley, K. M. Mohler, C. J. March, and R. J. Armitage. 1993. Identification of distinct low affinity receptor for human interleukin-4 on pre-B cells. Blood. 81:2998-3005.

24. Fishkin, B. G., F. J. Glassy, P. G. Hattersley, F. M. Hirose, and H. L. Spiegelberg. 1970. IgD multiple myeloma: a report of five cases. Am. J. Clin. Pathol. 53:209-214. 
25. Spiegelberg, H. L., and H. M. Grey. 1968. The catabolism of human gamma G myeloma proteins in heterologous species. J. Immunol. 101:711-716.

26. Lundgren, M., U. Persson, P. Larsson, C. Magnusson, C. I. E. Smith, L. Hammarström, and E. Severinson. 1989. Interleukin 4 induces synthesis of IgE and IgG4 in human B cells. Eur. J. Immunol. 19:1311.

27. Gascan, H., J.-F. Gauchat, M.-G. Roncarolo, H. Issel, H. Spits, and J. E. De Vries. 1991. Human B cell clones can be induced to proliferate and to switch to IgE and IgG4 synthesis by interleukin-4 and a signal provided by activated CD4 ${ }^{+} \mathrm{T}$ cell clones. J. Exp. Med. 173:747-750.

28. Ishizaka, A., Y. Sakyama, M. Nakanishi, K. Tomizawa, E. Oshika, D. Kojima, Y. Taguchi, E. Kandit, and S. Matsumoto. 1990. The inductive effect of interleukin-4 on IgG4 and IgE synthesis in human peripheral blood lymphocytes. Clin. Exp. Immunol. 79:392-396.

29. Yount, W. J., R. C. Fuller, and J. G. Simmons. 1979. Distribution of IgG subclasses in human B lymphocytes: evidence for dual expression of subclasses in surface and cytoplasmic IgG in minor B lymphocyte subpopulations. J. Immunol. 124:431-436.

30. Duchosal, M. A., S. A. Eming, P. J. McConahey, and F. J. Dixon. 1992. Characterization of hu-PBL-SCID mice with high human immunoglobulin serum levels and graft-versus-host disease. Amer. J. Pathol. 141(5):1097-1113.

31. Duchosal, M. A., S. Eming, P. J. McConahey, and F. J. Dixon. 1992. The hu-PBL-SCID mouse model. Long-term human serologic evolution associated with the xenogeneic transfer of human peripheral blood leukocytes into SCID mice. Cell. Immunol. 139:468-477.

32. Torbett, B. E., G. Picchio, and D. E. Mosier. 1991. hu-PBL-SCID mice: a model for human immune function, AIDS, and lymphomagenesis. Immunol. Rev. 124:139-164.

33. O'Connor, R., R. McPherson, M. Mellon, R. Hong, M. Borzy, and R. Hamburger. 1979. Reversal of monoclonal immunoglobulin production and hyperimmunoglobulinemia $\mathrm{E}$ by thymic epithelial transplantation in severe combined immunodeficiency. Pediatr. Res. 13:452. (Abstr.) 